\title{
Anxiety and depression levels are different in patients between allergic rhinitis and asthma
}

\author{
Aysenaz Özcan ${ }^{1 *}$, Adile Berna Dursun², Tugba Cicek \\ From 3rd WAO International Scientific Conference (WISC) 2014 \\ Rio de Janeiro, Brazil. 6-9 December 2014
}

\section{Background}

AR and asthma, often seen in younger adults and had social- psychological burden, are common chronic diseases. The objective of the study was to determine and compare the prevalence of anxiety and depression in allergic rhinitis (AR) and asthmatics.

\section{Methods}

Subjects without known psychiatric diseases were consecutively recruited from pulmonary and allergy outpatient clinics at the third level hospitals. Diagnosis of asthma and AR was based on GINA and ARIA guideline, respectively. Only patients without asthma were chosen for AR group in order to compare with asthma. Depression and anxiety symptoms were evaluated using Beck Depression Inventory (BDI) and Beck Anxiety Inventory (BAI).

\section{Results}

Study group consisted of 60 patients-30 with asthma and 30 with AR. All patients had moderate-to severe diseases. AR group was younger; but the mean disease duration was not significantly statistically different. AR group had higher education history than those of asthmatics. Number of smokers in both groups were equal. Female gender was predominant in both groups. In asthmatics, $53.3 \%$ had positive skin prick test with aeroallergens. Polysensitization rate was $56.25 \%$ and $63.3 \%$ in asthmatics and AR group, respectively. The most common sensitization pattern was mite plus mould sensitization. The mean BDI and BAI scores were 11.47 \pm 11.14 and $15.22 \pm 11.31$ in the whole group. Both BDI and BAI scores were significantly statistically different in the study groups (Table 1). Asthma and low level of

\footnotetext{
${ }^{1}$ Ataturk Chest Diseases and Thoracic Surgery Training and Research Hospital, Turkey

Full list of author information is available at the end of the article
}

Table 1 Beck Depression Index and Beck Anxiety Index in the study population

\begin{tabular}{cccc}
\hline & Asthma $\mathrm{n}=30$ & Allergic rhinitis $\mathrm{n}=30$ & $\mathrm{p}$ \\
\hline $\mathrm{BDI}$, mean $\pm \mathrm{SD}$ & $15.63 \pm 12.61$ & $7.3 \pm 5.6$ & .006 \\
\hline $\mathrm{BAl}$, mean $\pm \mathrm{SD}$ & $21.23 \pm 11.74$ & $9.2 \pm 6.9$ & .000 \\
\hline
\end{tabular}

education was found as the important factors for BAI in multiple regression analysis.

\section{Conclusions}

AR patients without asthma seem to have better coping mechanism than that of asthmatics.

\section{Authors' details}

${ }^{1}$ Ataturk Chest Diseases and Thoracic Surgery Training and Research Hospital, Turkey. ${ }^{2}$ Recep Tayyip Erdogan University School of Medicine, Turkey.

Published: 8 April 2015

doi:10.1186/1939-4551-8-S1-A52

Cite this article as: Özcan et al:: Anxiety and depression levels are different in patients between allergic rhinitis and asthma. World Allergy Organization Journal 2015 8(Suppl 1):A52.

Submit your next manuscript to BioMed Central and take full advantage of:

- Convenient online submission

- Thorough peer review

- No space constraints or color figure charges

- Immediate publication on acceptance

- Inclusion in PubMed, CAS, Scopus and Google Scholar

- Research which is freely available for redistribution 